UDC 658.62:005

JEL Classification: L15, 032

http://doi.org/10.21272/mmi.2019.2-24

Yuliia Vasutinska,

National University of Food Technology, Ukraine

Nataliia Kuzminska,

Ph.D., Associated Professor, Igor Sikorsky Kyiv Polytechnic Institute, Ukraine

\title{
ESTIMATING THE DEGREE OF NOVELTY OF A NEW PRODUCT: INNOVATIVE APPROACH
}

Abstract. This paper summarizes the arguments and counterarguments within the scientific discussion on the issue definition of the structure and degree of novelty of the product in accordance with the classification of novelty in terms of its functional orientation. The main purpose of the research is to develop its own methodology for assessing the degree of novelty of a new product, as a quantitative characteristic, on the basis of comparison with the analogue product. To construct a methodology, it is important to prioritize the scale of the novelty of a product: a regional, national or global market. The determination of the required scale of novelty depends on the choice of the main analogue product and the choice of the consumer group. Systematization literary sources and approaches for solving the problem of determining the level of novelty of goods indicates that there is no universal method for assessing the degree of its novelty. The relevance of the decision of this scientific problem is to assess the degree of novelty of the product because in reality the market is saturated with pseudo-new products. The concept of novelty is relative and does not have clearly defined requirements. Investigation of the topic of quantitative evaluation of the novelty of a product in the paper is carried out in the logical sequence. The essence and structure of novelty are determined, the level of novelty is estimated for each species and as a result, the total integral indicator is derived. Methodological tools of the research methods are mathematical methods of action with matrices and methods for analysing the hierarchies of pairwise comparisons proposed by Thomas $L$. Saaty. Comparison of indicators according to different criteria is carried out on a nine-point scale. Integral indicator of the level of novelty of a new product is calculated as the average geometric indices of production, market and consumer novelty. Determining the level of novelty of a new product is carried out on a scale from 0 to 1 , which allows to determine the novelty, both for each type of novelty and for the general level. An empirical study has been conducted to determine the validity of this method of determining level of novelty of a new product. The results of the research can be useful for the assessment of the enterprises of their new products and as a component of the assessment of the innovation activity of enterprises.

Keywords: novelty, a new product, the types of novelty, the degree of novelty, the structure of novelty.

Introduction. Innovation development is exactly that driving force that can bridge the gap with developed countries and leads to a significant increase in competitiveness of the economy of developing countries. According to the World Bank's research concerning assessment of innovation development of the countries in the world the Global Innovation Index (GII) aims to capture the multi-dimensional facets of innovation by providing a rich database of detailed metrics for 126 economies, which represent $90.8 \%$ of the world's population and $96.3 \%$ of global GDP. According to 2018, Switzerland ranked the 1 st place, Ukraine - 43rd, Yemen - 126th (Dutta et al, 2018). Therefore, for a modern enterprise that seeks for stable development, one of the factors that will give it an advantage among others is creation new products. Currently, concept of a new product is sufficient relative. A new product for a particular enterprise may already be known to other enterprises. Therefore, it is important to determine the degree of novelty of a product, as a quantitative characteristic of the differences of a new product from previous analogues.

Literature Review. Works of many domestic and foreign scientists, such as Kotler F. (Kotler, 2007), Chukhrai N. (Chukhrai \& Patora, 2006), Hikovata N. (Hikovata, 2006), Illiashenko S. (Illiashenko, 2007), Nahornyi Ye. (Nahornyi, 2009) and others, who investigated issues of the novelty of products, were

Cite as: Vasutinska, Y., \& Kuzminska, N. (2019). Estimating the Degree of Novelty of a New Product: Innovative Approach. Marketing and Management of Innovations, 2, 282294. http://doi.org/10.21272/mmi.2019.2-24 
aimed at identifying classification features of new products and types of its novelty, novations and innovations.

Question of counting novelty degree of new products was investigated by Illiashenko S. (Illiashenko, 2007), Nahornyi Ye. (Nahornyi, 2009), Shcherban V. (Shcherban, 2007), Yastremska O. (Yastremska \& Vereshchahina, 2010), Hikovata N. (Hikovata, 2006), Yuquan Zh., Hongru WU (Yuquan \& Hongru, 2017) and others. Ilyashenko S. (Illiashenko, 2007) determines the degree of novelty by means of Weber's law as the ratio of the minimum change in the intensity of the stimulus of a new product to the intensity of the stimulus of the existing product.

Balabanova L. and Brindina O. (Balabanova\&Brindina, 2006) are using an integral criterion for assessing the degree of novelty as a product of weighting factor and expert scores in points. In the writings of Shcherbany V. (Shcherban, 2007), Grinev V. (Grinev, 2004), Zavyalov P. (Zavyalov, 2002) and others the degree of novelty is determined by the form, functional and design parameters of the product, which are measured in points, and, depending on them, give a slight novelty, a new type of product and a qualitatively new product. Nahornyi Ye. (Nahornyi, 2009) and Pankruhin A. (Pankruhin, 2007) expand the gradation of novelty and distinguish such levels as a completely new product, a high degree of novelty, significant, sufficient, low and not a real degree. Such methods as expert assessments, psychological scales, ball scores, per cent gradation and others are used.

Some scientists, such as M. J. Nieto and L. Santamaría (Nieto \& Santamaria, 2005), M. Knell and M. Srholec (Knell \& Srholec, 2009) solve the problem of finding and describing the factors in achieving a higher degree of novelty in product innovation.

Scientists W.-L. Hsieh, P. Ganotakis, M. Kafouros, Ch. Wang (Hsieh et al., 2017) focused on problems how collaboration with domestic partners assists in the formation of collaborations with foreign partners, how knowledge from these collaborations is associated with product innovation at different levels of novelty, and how the relationship between the level of innovation novelty and firm growth is influenced by whether the focal firm engages in open or closed innovation and the origin of the collaborator (foreign or domestic). Such scientist as R. Scott (Scott, 2012) developed a theory to explain how the degree of novelty of new products impacts market discourse, which is used as a sense making mechanism to reduce uncertainty caused by the new products. Research of P. Sarkar and A. Chakrabarti (Sarkar and Chakrabarti, 2006) focused on the determination of novelty only of engineering products. Analysis of works of domestic and foreign scientists has shown that there is no single integrated system of classifying types and degrees of the novelty of products; there are no established standards of novelty, both at certain enterprises and at the state degree. Limitation and scarcity of information greatly complicate the creation of a universal methodology for assessing the degree of novelty of a new product. Due to the dynamism of scientific and technological progress development, which leads to a significant reduction in the continuity of life cycle of products, outlined issues are difficult to solve, and it makes them constantly relevant and requires the development of modern methods that would be universal and simply.

Aims of the paper is the description of method of determining level of novelty of a new product on a scale from 0 to 1 , by using which it will be possible to compare not only homogeneous, but also different products.

Methodology and research methods. According to the State Statistics Service of Ukraine, «minimum degree of a novelty for enumeration of any change to category «innovation» is defined as a new one for the enterprise (organization). The product can already be used (produced) at other enterprises (organizations), but if it is a new one or significantly improved for this enterprise (organization), then such a change is considered for it as innovation» (Karmazina, 2016). Innovative production includes products that are new or significantly improved in terms of its properties or methods of usage. Innovative products are divided into new products for the market and for the enterprise. The 
market is understood as an own idea of an enterprise (organization) about the market, where it operates, and which can be composed only with reporting enterprise (Karmazina, 2016).

Degree of novelty is a measure of the difference of a new product from analogues, which are already known at the market and among consumers. The main reasons for difficulty of finding this indicator are lack of certain legal requirements and norms for recognizing the product as a new one, limitations and lack of information, subjectivity and relativity of researchers' assessments.

The most expedient way to develop a method for determining the overall degree of novelty of a product is a classification of novelty by its functional orientation. According to this criterion, consumer, market and production novelty of a product are distinguished. The overall indicator of a novelty is proposed to be calculated by using indicators of novelty for each of its types separately because in most cases they are more ponderable and significant.

To develop an effective method for determining the degree of novelty it is necessary to perform the following tasks:

- definition of types of novelty;

- choice of determining factors for each type of novelty;

- choice of appropriate indicators of measurement for each type of novelty;

- definition of formulas for the calculation of the degree of novelty;

- accessibility and easiness in usage;

- consistency of results for each type of novelty to calculate the integrated indicator.

In the context of this research, the concept of production, market and consumer novelty should be understood as follows:

- production novelty characterizes the degree of usage of new technologies, a new way of production organization, new raw materials in the production of products;

- market novelty is determined by the proportion of new products among analogues at a certain point in time, characterizes the degree of awareness of consumers about the product and its properties;

- consumer novelty characterizes the measure and method of satisfaction of existing and new consumer needs with a new product in comparison with the previously known.

For constructing methodology, it is important to determine the preliminary conditionality of the scale of the novelty of the product. It can be a regional, national or global market. According to this, there is a difference in the choice of the subject. The scale of the novelty of product is chosen by depending on the purpose of the research and the market in which the company operates. The choice of the scale of novelty is shown at Figure 1.

The choice of basic analogue product for comparison and the choice of consumer group depend on the determination of the required scale of novelty. If the company wants to determine the novelty of its product on the regional market, where there are no competitors in this industry, then the same product is being chosen as the base product of the same company, which is closest to its properties to a new product. In the case of competitors, the most similar product, taking into account the goods of competitors, is chosen as the basic analogue product. In the role of consumers there are people of a certain geographically defined market. When determining the novelty at the national level, it is necessary to take into account all producers of a certain type of product in this field and it is advisable to form a group of consumers from all over the country.

After choosing the required scale of novelty and relevant subjects, the degree of novelty is defined for each of its types. The main defining characteristics and the corresponding calculation methods are presented in Table 1. To determine the degree of production and consumer novelty, the Analytic Hierarchy Process method (AHP) of Thomas L. Saaty (Saaty, 1989) is used. 


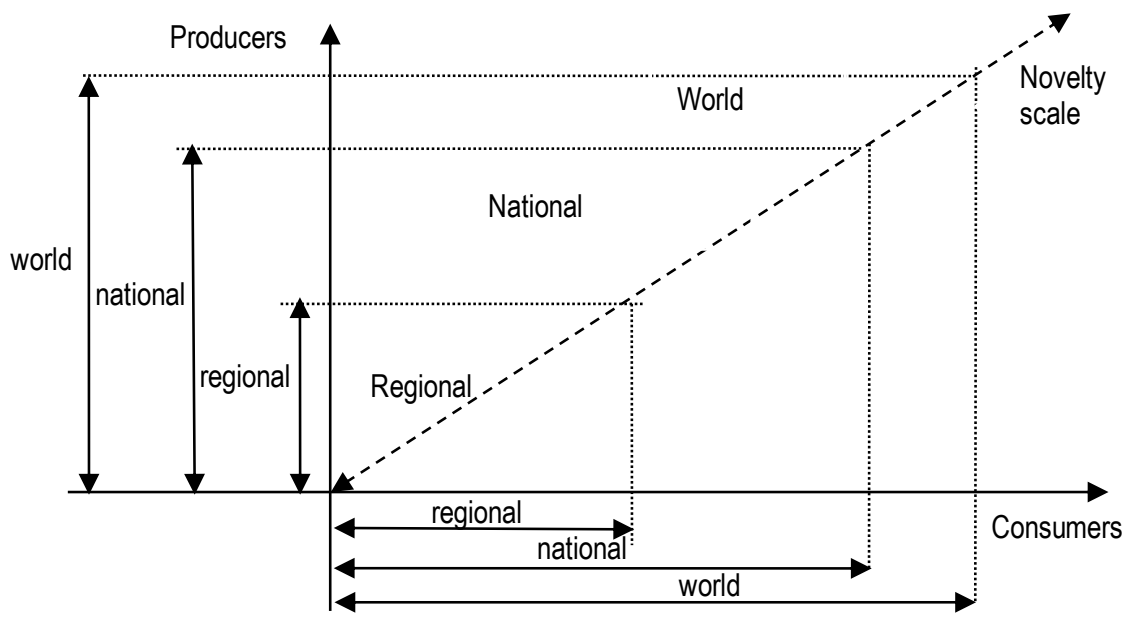

Figure 1. The choice of the scale of novelty

Source: developed by the author.

Table 1. The types and main defining characteristics of the novelty of a product

\begin{tabular}{|c|c|c|c|}
\hline \multirow{2}{*}{ Characteristics } & \multicolumn{3}{|c|}{ Types of novelty } \\
\hline & production & market & consumer \\
\hline Determiner & producer & producer and consumer & consumer \\
\hline $\begin{array}{l}\text { Main defining } \\
\text { characteristics }\end{array}$ & $\begin{array}{l}\text { - organization of production } \\
\text { - raw material for } \\
\text { production } \\
\text { - production technology } \\
\text { - external product } \\
\text { parameters } \\
\text { - production equipment }\end{array}$ & $\begin{array}{l}\text { - } \text { advertising volume } \\
\text { - } \text { brand recognition } \\
\text { - } \text { marketing company } \\
\text { - } \quad \text { time and methods of } \\
\text { disseminating information } \\
\text { - } \quad \text { share among similar goods } \\
\text { - } \quad \text { volume and geography of } \\
\text { marketing sales } \\
\text { - } \quad \text { the appearance of a new } \\
\text { product }\end{array}$ & 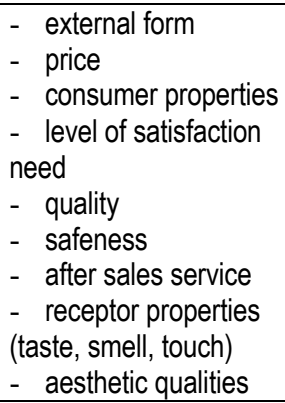 \\
\hline $\begin{array}{l}\text { Calculation } \\
\text { methods }\end{array}$ & $\begin{array}{l}\text { The Analytic Hierarchy } \\
\text { Process of Thomas L. Saaty }\end{array}$ & $\begin{array}{l}\text { The product life cycle }(\mathrm{LC}) \\
\text { modelling, sales analysis }\end{array}$ & $\begin{array}{l}\text { The Analytic Hierarchy } \\
\text { Process of Thomas } \\
\text { L. Saaty }\end{array}$ \\
\hline Designation & $N_{P}$ & $N_{M}$ & $N_{C}$ \\
\hline
\end{tabular}

Source: developed by the author.

According to this method, the comparison of indicators according to different criteria is made using a nine-point scale. Comparing two objects $A$ and $B$ to prioritize or change some of the parameter of one of objects, the following levels of change (advantages) between $A$ and $B$ and relevant grades are selected: no change (equal importance advantage A over B) - 1; slight change (moderate importance advantage A over B) - 3; significant change (strong importance advantage A over B) - 5; explicit change (very strong or demonstrated importance of advantage A over B) - 7; explicit absolute change (extreme 
importance of advantage A over B) - 9; intermediate values of change (advantages A over B) - 2, 4, 6 , 8. To determine the degree of production novelty, the hierarchical structure proposed in Figure 2 is used. After constructing the hierarchy, the priorities of all nodes of lower levels in relation to the higher ones are determined. They are the criteria according to the goal and alternatives in relation to each criterion. Definition of manufacturing novelty is an exclusive right of the manufacturer. Only he/she has complete information about all conditions for the manufacture of goods, so a group of experts should consist of professionals who created the product from its idea to the market promotion. To determine priorities $p_{v_{i}}, i=\overline{1,5}$ of criteria (components of the production process) in relative to production novelty (goal), the matrix of pairwise comparisons is used where the degree of the advantage of one component over another is indicated respectively.

Goal:

Covering criteria:

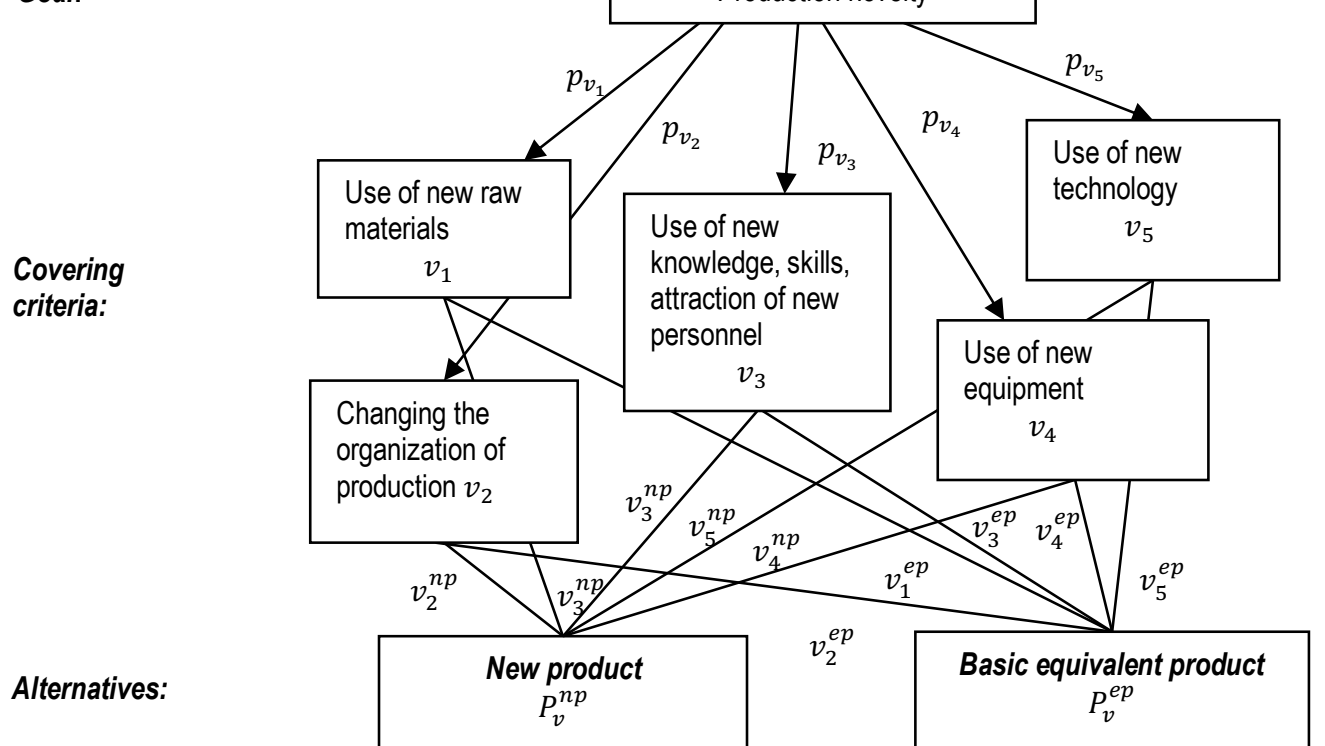

Figure 2. The hierarchical structure of production novelty

Source: developed by the author.

At that evaluation of advantage of criterion $v_{i}$ over $v_{j}$ is filled in cell $i j$, and that is $v_{i j}\left(1 \leq v_{i j} \leq\right.$ 9), then cell with number $j i$ corresponds with estimate $\frac{1}{v_{i j}}$, and matrix of pairwise comparisons by its construction that is inverse-symmetric. An indicator of coherence of expert judgments is latent root $\lambda_{\max }$ of the matrix of pairwise comparisons.

If $\lambda_{\max }=n$ (where $n$ is a number of objects or types of actions in the matrix), then the matrix is agreed. The closer this value to the number $n$, the more agreeable and exact is the result. You can find approximate values of priority vector $\left(p_{v_{1}}, p_{v_{2}}, p_{v_{3}}, p_{v_{4}}, p_{v_{5}}\right)$ in several ways. In the case of matrix coherence, all methods will give the same exact result. If the matrix is not agreed, then the deviation of consistency can be expressed by the index of coherence $I C$ and by the relation of coherence $R C$. $R C$ value that is less or equal to 0,10 is considered as acceptable (Saaty, 1989). 
After finding priorities of criterion, the comparison of a new product and analogue product is made in order to change each criterion in accordance with Table 1. The results of the comparison and calculated priorities of a new product and analogue product are presented in Table 2.

Table 2. The priorities of alternatives in relation to the criteria of production novelty

\begin{tabular}{|c|c|c|c|c|}
\hline $\begin{array}{c}\text { Criteria } \\
v_{i}, i=\overline{1,5}\end{array}$ & $\begin{array}{l}\text { Priority of the } \\
\text { criteria } p_{v_{i}} \\
0 \leq p_{v_{i}} \leq 1 \\
\sum_{i=1}^{5} p_{v_{i}}=1\end{array}$ & $\begin{array}{c}\text { Relevant } \\
\text { grade criteria } \\
v_{i} \text { of a new } \\
\text { product to } \\
\text { equivalent } \\
\text { product } v_{i} \text {, } \\
1 \leq v_{i} \leq 9\end{array}$ & $\begin{array}{l}\text { Priority of a new } \\
\text { product } v_{i}^{n p} \\
v_{i}^{n p}=\frac{v_{i}}{v_{i}+1}\end{array}$ & $\begin{array}{l}\text { Priority of an equivalent product } \\
\qquad v_{i}^{e p} \\
v_{i}^{e p}=\frac{1}{v_{i}+1}\end{array}$ \\
\hline $\begin{array}{l}\text { 1. Use of new raw } \\
\text { materials }\left(v_{1}\right)\end{array}$ & $p_{v_{1}}$ & $v_{1}$ & $v_{1}^{n p}$ & $v_{1}^{e p}$ \\
\hline $\begin{array}{l}\text { 2. Changing the } \\
\text { organization of } \\
\text { production }\left(v_{2}\right)\end{array}$ & $p_{v_{2}}$ & $v_{2}$ & $v_{2}^{n p}$ & $v_{2}^{e p}$ \\
\hline $\begin{array}{l}3 \text { Use of new } \\
\text { knowledge, skills, } \\
\text { attraction of new } \\
\text { personnel }\left(v_{3}\right)\end{array}$ & $p_{v_{3}}$ & $v_{3}$ & $v_{3}^{n p}$ & $v_{3}^{e p}$ \\
\hline $\begin{array}{l}\text { 4. Use of new } \\
\text { equipment }\left(v_{4}\right)\end{array}$ & $p_{v_{4}}$ & $v_{4}$ & $v_{4}^{n p}$ & $v_{4}^{e p}$ \\
\hline $\begin{array}{l}\text { 5. Use of new } \\
\text { technology }\left(v_{5}\right)\end{array}$ & $p_{v_{5}}$ & $v_{5}$ & $v_{5}^{n p}$ & $v_{5}^{e p}$ \\
\hline
\end{tabular}

Source: developed by the author.

At the next stage, there is a priority of a new product $P_{v}^{n p}$ and analogue product (basic equivalent product) $P_{v}^{e p}$ in relation to production novelty using formulas (1), (2):

$$
\begin{aligned}
& P_{v}^{n p}=\sum_{i=1}^{5} p_{v_{i}} \cdot v_{i}^{n p}, \\
& P_{v}^{e p}=\sum_{i=1}^{5} p_{v_{i}} \cdot v_{i}^{e p},
\end{aligned}
$$

where $p_{v_{i}}$ - priority of the $i$-th criteria to the goal; $v_{i}^{n p}, v_{i}^{e p}$ - priorities of alternatives in relation to the $i$-th criteria.

As $P_{v}^{n p}$ and $P_{v}^{e p}$ are priorities of one level of the hierarchy, then $P_{v}^{n p}+P_{v}^{e p}=1$ at what $0,5 \leq$ $P_{v}^{n p} \leq 1$ and $0 \leq P_{v}^{e p} \leq 0,5$ for specific of choice of research objects. The degree of production novelty $N_{V}$ of a new product is proposed to be calculated according to the formula:

$$
N_{P}=1-\frac{P_{v}^{e p}}{P_{v}^{n p}}
$$

Indicator of production novelty $N_{P}$ is changing in terms $[0 ; 1]$. The closer the meaning is to 1 , the more the product has changed from production side with the comparison to similar product. If the value of this indicator is near to zero, then it means that in this new product there are no productive changes. 
The definition of consumer novelty is the most complex, because each consumer subjectively assesses the degree of change of a new product and evaluates those properties of goods that cannot be measured by physical units. A similar problem, namely, the problem of quantifying the value or property of an object, which is not measured by physical units, was solved by researchers in qualimetry (Raikhman \& Azghaldov, 1974). The issue of quantitative measurement of quality degree is simpler because certain national standards and technical conditions for the production of each type of products are defined by law, that is, there is a standard for comparison. In determining the novelty currently, there is no such standard and certain regulatory requirements. For the object of comparison, the nearest analogue product or generalizing image of the most similar, previously known product for a consumer is taken. Therefore, calculation of the degree of consumer novelty is proposed to conduct the same method, as well as for the production of novelty. The hierarchical structure of consumer novelty is presented in Figure 3.

Goal:

Criteria:

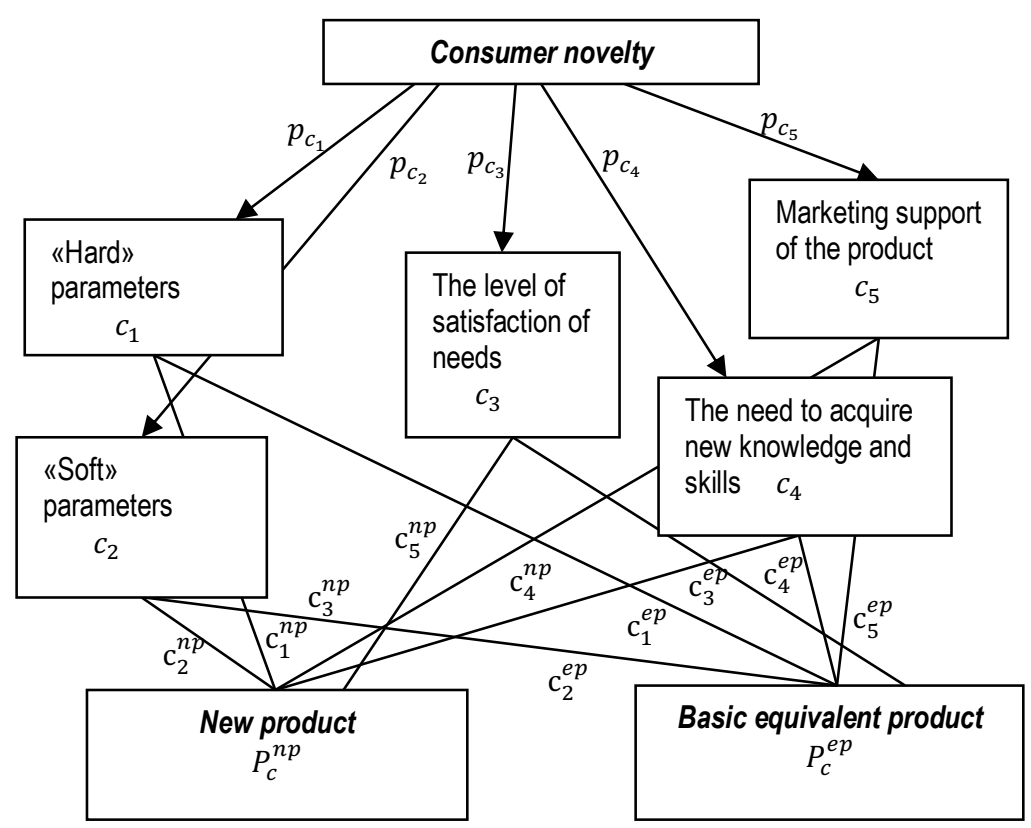

Figure 3. The hierarchical structure of consumer novelty of a product

Source: developed by the author.

Depending on the specifics of the investigated product, the criteria $C_{1}$ and $C_{2}$ may be presented by specific parameters of product that had changes and are most interesting to the researcher. The expert group for determining the consumer novelty consists of consumers of a certain territory, according to the scale of novelty definition.

Similar to calculation of production novelty, the priorities $p_{c_{j}}, j=\overline{1,5}$ - criteria $c_{j}$ are components of consumer novelty and they are defined. The comparison of a new product and analogue product in order to change on each criterion is made, that is, the assessment of advantage of the criterion $c_{i}$ above $c_{j}$ is filled in cell $i j$ and is $c_{i j}\left(1 \leq c_{i j} \leq 9\right)$, then cell with the number $j i$ will correspond to score $\frac{1}{c_{i j}}$, and 
the matrix of pairwise comparisons for its construction is inverse-symmetric. The results of the comparison and calculated priorities of a new product and analogue product are presented in Table 3 .

Table 3. The priorities of alternatives in relation to the criteria of consumer novelty

\begin{tabular}{|c|c|c|c|c|}
\hline $\begin{array}{c}\text { Criteria } \\
c_{i}, i=\overline{1,5}\end{array}$ & $\begin{array}{c}\text { Priority of the } \\
\text { criteria } p_{c_{i}} \\
0 \leq p_{c_{i}} \leq 1 \\
5\end{array}$ & $\begin{array}{c}\text { Relevant grade } \\
\text { criteria } c_{i} \\
\text { of a new product } \\
\text { to equivalent } \\
\text { product } c_{i}, 1 \leq \\
v_{i} \leq 9\end{array}$ & $\begin{array}{c}\text { Priority of a new } \\
\text { product } c_{i}^{n p} \\
c_{i}^{n p}=\frac{v_{i}}{v_{i}+1}\end{array}$ & $\begin{array}{c}\text { Priority of an } \\
\text { equivalent product } \\
c_{i}^{e p},\end{array}$ \\
\hline $\begin{array}{c}\text { 1. «Hard» parameters } \\
\left(c_{1}\right)\end{array}$ & $p_{c_{i}}=1$ & $c_{1}$ & $c_{1}^{e p}=\frac{1}{v_{i}+1}$ \\
\hline $\begin{array}{c}\text { 2. «Soft» parameters } \\
\left(c_{2}\right)\end{array}$ & $p_{c_{2}}$ & $c_{2}$ & $c_{2}^{n p}$ & $c_{1}^{e p}$ \\
\hline $\begin{array}{c}\text { 3. The level of } \\
\text { satisfaction of needs }\left(c_{3}\right)\end{array}$ & $p_{c_{3}}$ & $c_{3}$ & $c_{3}^{n p}$ & $c_{2}^{e p}$ \\
\hline $\begin{array}{c}\text { 4. The need to acquire } \\
\text { new knowledge and } \\
\text { skills }\left(c_{4}\right)\end{array}$ & $p_{c_{4}}$ & $c_{4}$ & $c_{4}^{n p}$ & $c_{3}^{e p}$ \\
\hline $\begin{array}{c}\text { 5. Marketing support of } \\
\text { the product }\left(c_{5}\right)\end{array}$ & $p_{c_{5}}$ & $c_{5}$ & $c_{5}^{n p}$ & $c_{4}^{e p}$ \\
\hline
\end{tabular}

Source: developed by the author.

The priority of a new product $P_{c}^{n p}$ and an analogue product (basic equivalent product) $P_{c}^{e p}$ in relation to consumer novelty are calculated by formulas (4), (5):

$$
\begin{aligned}
& P_{c}^{n p}=\sum_{i=1}^{5} p_{c_{i}} \cdot c_{i}^{n p}, \\
& P_{c}^{e p}=\sum_{i=1}^{5} p_{c_{i}} \cdot c_{i}^{e p},
\end{aligned}
$$

where $p_{c_{i}}$ is the priority of the $i$-th criteria to the goal; $c_{i}^{n p}, c_{i}^{e p}$ are the priorities of alternatives in relation to the $i$-th criteria.

The degree of production novelty $N_{C}$ of a new product is proposed to be calculated according to the formula:

$$
N_{C}=1-\frac{P_{C}^{e p}}{P_{C}^{n p}}
$$

Indicator of production novelty $N_{C}$ also varies within the range $[0 ; 1]$, the closer its value is to 1 , the newer investigated product is in costumer's view. If the value of this indicator is close to zero, then the consumer does not notice any changes in a new product. The market novelty of product characterizes term of the presence of goods at the market, its share among the goods-analogues, nature of changes in sales. For its calculation (Figure 4) next data is used where $T$ is the duration of LC of this type of products; $T_{0}$ is a time of entering on the market of the nearest analogue product; $t$ is a time of entering new product on market; $p$ is share of sales of a new product among analogues. The formula for finding the degree of market novelty $N_{M}$ of a new product can be written as follow: 


$$
N_{M}=\sqrt{p\left(1-\frac{t}{T-T_{0}}\right)}
$$

The indicator of market novelty $N_{M}$ varies in the range $[0 ; 1]$, the closer its value is to 1 , the newer researched product is for the market. The product of the highest market novelty is a product that appears only on the market and has no analogues. The degree of market novelty decreases with increasing time of entry on market and number of analogues. A significant influence on market novelty is made by factors such as brand and brand information, advertising, marketing campaign, the capacity of manufacturer of product etc. The integral index of the degree of novelty of a new product $\mathrm{N}$ is proposed to be calculated through the indices of production, market and consumer novelty by the formula:

$$
N=\sqrt[3]{N_{P} \cdot N_{M} \cdot N_{C}}
$$

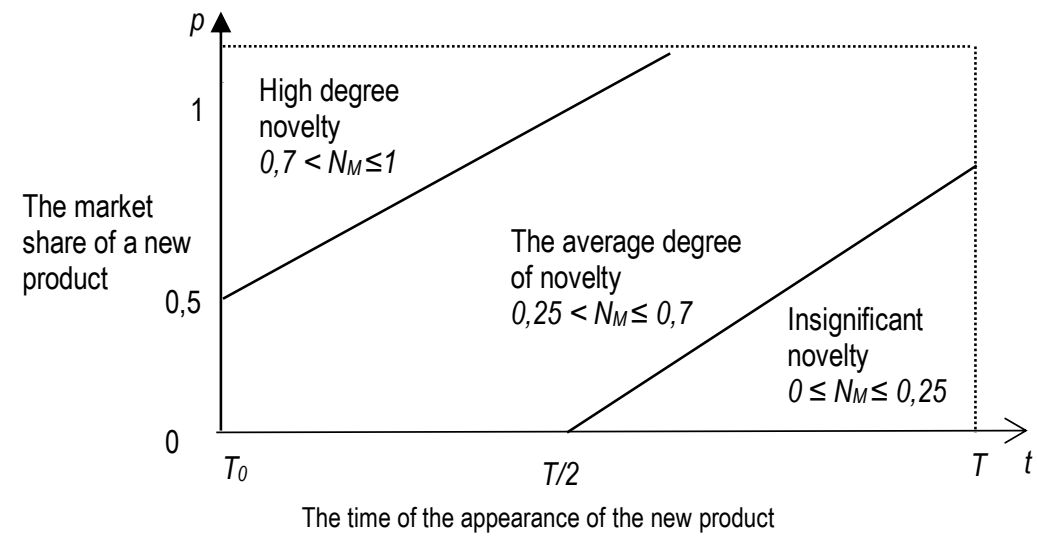

Figure 4. The index of the degree of market novelty

Source: developed by the author.

For the ranking and interpretation of the indicator of the level of novelty, the desirable scale of E. Harrington (1965) is used, which is presented in Table 4. It relates to psychophysical scales, and with its help correlation between physical and psychological parameters is set.

Table 4. The index of the degree of novelty of a new product

\begin{tabular}{l|c}
\multicolumn{1}{c|}{ Degree of novelty } & Index \\
\hline Radical novelty (product-pioneer) & $1,00-0,80$ \\
The explicit, essential novelty & $0,79-0,63$ \\
Satisfactory novelty & $0,62-0,37$ \\
Insignificant novelty & $0,36-0,20$ \\
Questionable novelty & $0,19-0,00$ \\
\hline
\end{tabular}

Source: (Harrington, 1965)

Results. The product «Ultra-Pasteurized Chocolate Milkshake» has been tested by the proposed method of determining level of novelty of a new product. As the analogue product was selected milk with the addition of food flavours. For calculation values in tables 5, 6 and (9) - (16) used formulas (1) - (8) and tables 2,3. 
Table 5. The priorities of alternatives in relation to the criteria of production novelty for «UltraPasteurized Chocolate Milkshake»

\begin{tabular}{|l|c|c|c|c|}
\hline \multicolumn{1}{c|}{$\begin{array}{c}\text { Criteria } \\
v_{i}, i=\overline{1,5}\end{array}$} & $\begin{array}{c}\text { Priority of the } \\
\text { criteria } p_{v_{i}} \\
0 \leq p_{v_{i}} \leq 1 \\
\sum_{i=1}^{5} p_{v_{i}}=1\end{array}$ & $\begin{array}{c}\text { Relevant grade criteria } \\
v_{i} \text { of a new product to } \\
\text { equivalent product } v_{i}, \\
1 \leq v_{i} \leq 9\end{array}$ & $\begin{array}{c}\text { Priority of a new } \\
\text { product } v_{i}^{n p} \\
v_{i}^{n p}=\frac{v_{i}}{v_{i}+1}\end{array}$ & $\begin{array}{c}\text { Priority of an } \\
\text { equivalent product } \\
v_{i}^{e p}, \\
v_{i}^{e p}=\frac{1}{v_{i}+1}\end{array}$ \\
\hline $\begin{array}{l}\text { 1. Use of new raw } \\
\text { materials }\left(v_{1}\right)\end{array}$ & 0,2 & 3 & $3 / 4$ & $1 / 4$ \\
\hline $\begin{array}{l}\text { 2. Changing the } \\
\text { organization of } \\
\text { production }\left(v_{2}\right)\end{array}$ & 0,3 & 3 & $3 / 4$ & $1 / 4$ \\
\hline $\begin{array}{l}\text { 3 Use of new } \\
\text { knowledge, skills, } \\
\text { attraction of new } \\
\text { personnel }\left(v_{3}\right)\end{array}$ & 0,1 & 2 & $2 / 3$ & $1 / 3$ \\
\hline $\begin{array}{l}\text { 4. Use of new } \\
\text { equipment }\left(v_{4}\right)\end{array}$ & 0,1 & 1 & $1 / 2$ & $1 / 2$ \\
\hline $\begin{array}{l}5 . \text { Use of new } \\
\text { technology }\left(v_{5}\right)\end{array}$ & 0,3 & 3 & $3 / 4$ & $1 / 4$ \\
\hline
\end{tabular}

Source: developed by the author.

$$
\begin{aligned}
& P_{v}^{n p}=0,2 \cdot \frac{3}{4}+0,3 \cdot \frac{3}{4}+0,1 \cdot \frac{2}{3}+0,1 \cdot \frac{1}{2}+0,3 \cdot \frac{3}{4}=0,72, \\
& P_{v}^{e p}=0,2 \cdot \frac{1}{4}+0,3 \cdot \frac{1}{4}+0,1 \cdot \frac{1}{3}+0,1 \cdot \frac{1}{2}+0,3 \cdot \frac{1}{4}=0,28 \\
& N_{P}=1-\frac{0,28}{0,72}=0,61 .
\end{aligned}
$$

Table 6. The priorities of alternatives in relation to the criteria of consumer novelty for "Ultra-Pasteurized Chocolate Milkshake»

\begin{tabular}{|c|c|c|c|c|}
\hline Criteria & $\begin{array}{c}\text { Priority of the } \\
\text { criteria } p_{c_{i}} \\
0 \leq p_{c_{i}} \leq 1 \\
c_{i}, i=\overline{1,5}\end{array}$ & $\begin{array}{c}\text { Relevant grade } \\
\text { criteria } c_{i} \\
\text { of a new product to } \\
\text { equivalent product } \\
c_{i}, 1 \leq v_{i} \leq 9\end{array}$ & $\begin{array}{c}\text { Priority of a new } \\
\text { product } c_{i}^{n p} \\
c_{i}^{n p}=\frac{v_{i}}{v_{i}+1}\end{array}$ & $\begin{array}{c}\text { Priority of an } \\
\text { equivalent product } \\
c_{i}^{e p}, \\
c_{i}^{e p}=\frac{1}{v_{i}+1}\end{array}$ \\
\hline 1. «Hard» parameters $\left(c_{1}\right)$ & 0,2 & 8 & $8 / 9$ & $1 / 9$ \\
\hline 2. «Soft» parameters $\left(c_{2}\right)$ & 0,2 & 6 & $6 / 7$ & $1 / 7$ \\
\hline $\begin{array}{c}\text { 3. The level of satisfaction of } \\
\text { needs }\left(c_{3}\right)\end{array}$ & 0,3 & 3 & $4 / 4$ & $1 / 5$ \\
\hline $\begin{array}{c}\text { 4. The need to acquire new } \\
\text { knowledge and skills }\left(c_{4}\right)\end{array}$ & 0,3 & 4 & $3 / 4$ & $1 / 4$ \\
\hline $\begin{array}{c}\text { 5. Marketing support of the } \\
\text { product }\left(c_{5}\right)\end{array}$ & 0,1 & 3 & & $3 / 5$ \\
\hline
\end{tabular}

Source: developed by the author.

$$
\begin{aligned}
& P_{v}^{n p}=0,2 \cdot \frac{8}{9}+0,2 \cdot \frac{6}{7}+0,3 \cdot \frac{3}{4}+0,3 \cdot \frac{4}{5}+0,1 \cdot \frac{3}{4}=0,88 \\
& P_{v}^{e p}=0,2 \cdot \frac{1}{9}+0,2 \cdot \frac{1}{7}+0,3 \cdot \frac{1}{4}+0,3 \cdot \frac{1}{5}+0,1 \cdot \frac{1}{4}=0,21
\end{aligned}
$$




$$
N_{\mathrm{C}}=1-\frac{0,21}{0,88}=0,76
$$

To determine market novelty, as fraction $p$ was taken fraction milkshakes new products of JSC «Milk Alliance» on the Ukrainian market. The duration of $L C$ of this type of products $T=12 ; T_{0}=6$ is a time of entering on the market of the nearest analogue product $t=1$ is a time of entering new product on market, $p=0,9$ is share of sales of a new product among analogues.

$$
\begin{aligned}
& N_{M}=\sqrt{0,9\left(1-\frac{1}{12-6}\right)}=0,75 \\
& N=\sqrt[3]{0,61 \cdot 0,76 \cdot 0,75}=0,70
\end{aligned}
$$

The proposed method also was used to assess the novelty of others new products of JSC «Milk Alliance». The results are presented in Table 7.

Table 7. Indices of novelty of new products JSC «Milk Alliance»

\begin{tabular}{|c|c|c|c|c|c|c|}
\hline № & $\begin{array}{c}\text { Product } \\
\text { name }\end{array}$ & $\begin{array}{c}\text { Production } \\
\text { novelty }\end{array}$ & Market novelty & $\begin{array}{c}\text { Consumer } \\
\text { novelty }\end{array}$ & $\begin{array}{c}\text { Integral } \\
\text { index }\end{array}$ & $\begin{array}{c}\text { Degree of } \\
\text { novelty }\end{array}$ \\
\hline 1 & Ayran with dill, 1.8\% fat & 0,61 & 0,65 & 0,55 & 0,59 & $\begin{array}{c}\text { satisfactory } \\
\text { novelty }\end{array}$ \\
\hline 2 & $\begin{array}{c}\text { UHT Lactose-free Drinking Cow } \\
\text { Milk, 3,2\% fat }\end{array}$ & 0,44 & 0,51 & 0,55 & 0,49 & $\begin{array}{c}\text { satisfactory } \\
\text { novelty }\end{array}$ \\
\hline 3 & $\begin{array}{c}\text { Ultra-Pasteurized Chocolate } \\
\text { Milkshake }\end{array}$ & $\mathbf{0 , 6 1}$ & $\mathbf{0 , 7 5}$ & $\mathbf{0 , 7 6}$ & $\mathbf{0 , 7 0}$ & $\begin{array}{c}\text { the explicit, } \\
\text { essential } \\
\text { novelty }\end{array}$ \\
\hline 4 & $\begin{array}{c}\text { Apple and Strawberry Cottage } \\
\text { Cheese Paste 4,2\% fat }\end{array}$ & 0,16 & 0,45 & 0,38 & 0,31 & $\begin{array}{c}\text { insignificant } \\
\text { novelty }\end{array}$ \\
\hline 5 & $\begin{array}{c}\text { Banana and Strawberry Yogurt } \\
\text { 2,5\% fat }\end{array}$ & 0,19 & 0,36 & 0,28 & 0,27 & $\begin{array}{c}\text { insignificant } \\
\text { novelty }\end{array}$ \\
\hline 6 & $\begin{array}{c}\text { Vershkovyi (Creamy) processed } \\
\text { cheese 55\% fat }\end{array}$ & 0,45 & 0,55 & 0,65 & 0,54 & $\begin{array}{c}\text { satisfactory } \\
\text { novelty }\end{array}$ \\
\hline
\end{tabular}

Source: developed by the author.

Conclusions. With the help of integral indicator of novelty degree of products, arbitrary products of different purposes can be compared, as well as the level of innovation activity of an enterprise. But very often it is more useful to determine indicators of the level of production, consumer and market novelty separately. Initial evaluation supports the effectiveness of this method. Further research is aimed at eliminating the limitations of this method to make it more general and compare it with other available approaches. The degree of novelty of product will be a determining factor for building the right strategy for promoting this product on the market and forming a common product innovation strategy of an enterprise. Developing and launching a new product on the market manufacturer depending on the values of the degree of novelty of new products, will use different strategies. Initial evaluation supports the effectiveness of this method. Further research is aimed at eliminating the limitations of this method to make it more general and compare it with other available approaches.

Author Contributions: Y.V., K.Z. - idea, conceptualization and calculation. 


\section{References}

Dutta, S., Lanvin, B., Wunsch-Vincent, S. (2018). Suggested citation: Cornell University, INSEAD, and WIPO (2018): The Global Innovation Index 2018: Energizing the World with Innovation. Ithaca, Fontainebleau, and Geneva. Retrieved 07.02.2018 from https://www.globalinnovationindex.org/gii-2018-report

Kotler, F. (2007). Marketing Essentials. Moscow: Viliams.

Chukhrai, N., Patora, R. (2006). Commodity Innovation Policy: Innovation Management at the Enterprise. Kyiv: Kondor.

Hikovata, N. (2006). Managing the process of creating a new product: marketing aspect. Kharkiv: KUZNETS KhNUE.

Illiashenko, S. (2007). Commodity Innovation Policy. Sumy: VTD «University book».

Nahornyi, Ye. (2009). The level of novelty of the goods as one of the indicators of the expediency of testing new products. Economics: problems of theory and practice, 1053-1064.

Nahornyi Ye. (2009). Methodical approaches to assessing the level of novelty of goods. Mechanism of regulation of the economy, 4 (2), 48- 58

Yuquan, Zh., Hongru, WU. (2017). The effect of R\&D novelty and openness decision on firms' catch-up performance: Empirical evidence from China. Advances in Social Science, Education and Humanities Research, volume 119. Retrieved 05.02.2018. https://pdfs.semanticscholar.org/3d03/61b1ffc91c0c3b8d058c76ec0695c1c81ecc.pdf

Nieto, M., Santamaría, L., (2005). Novelty of product innovation: the role of different networks. Business Economics Series. Working Paper, 05-65 (16).

Scott, R. Livengood (2012) Novelty Discourse. Proceedings of the New Frontiers in Management and Organizational Cognition Conference. Retrieved 28.01.2018 http://mural.maynoothuniversity.ie/4054/1/RS_Novelty.pdf

Knell, M., Srholec, M. (2009) The Novelty of Innovation and the Level of Developmen. Inclusive Growth, Innovation and Technological Change: education, social capital and sustainable development. Retrieved 01.02.2018 http://globelics2009dakar.merit.unu.edu/papers/1238518314 MK.pdf

Hsieh, W.-L., Ganotakis, P., Kafouros, M., Wang, Ch. (2017) Foreign and Domestic Collaboration, Product InnovationNovelty, and Firm Growthl. The Authors Journal of Product Innovation Management published by Wiley Periodicals, Inc. on behalf of Product Development \& Management Association DOI: 10.1111/jpim.12435

Sarkar, P., Chakrabarti, A. (2006) Assessing Degree of Novelty of Products to Ascertain Innovative Products. In: International Conference on Product Life Cycle Management PLM06, July 2006, Bangalore. Retrieved 05.02.2019 https://cpdm.iisc.ac.in/cpdm/ideaslab/paper_scans/UID_21.pdf

Shcherban, V. (2007). Product creation: marketing, design and technological support. Kyiv: Professional.

lastremska, O., Vereshchahina, O. (2010). Innovation Management. Kharkiv: INZhEK.

Karmazina, O. (2016). Scientific and innovation activity of Ukraine: statistical collection. Kyiv: State Enterprise «Information and Publishing Center of Gosstat of Ukraine».

Saaty, T. (1989). Making decisions. The Analytic Hierarchy Process. Moscow: Radio and communication.

Raikhman, E., Azghaldov, H. (1974). Expert methods in assessing the quality of products of goods. Moscow: Economy.

Pliuta, V. (1980). Comparative multivariate analysis in economic research: Taxonomy and factor analysis methods. Moscow: Statistics.

Harrington, E. (1965). The Desirability Function. Industrial Quality Control, 4, 494-498.

Balabanova, L., Brindina, O. (2006). Marketing commodity policy in the system of enterprise management. Donetsk: DonDUET.

Grinev, V. (2004). Product and innovation policy of the enterprise. Kyiv: MAUP.

Zavyalov, P. (2002). Marketing in schemes, figures, tables. Moscow: NFRA-M.

Pankruhin, A. (2007). Marketing. Moscow: Omega-L.

Ю. О. Васютинська, Національний університет харчових технологій (Україна);

Н. Л. Кузьмінська, к.е.н., доцент, Національний технічний університет України «Київський політехнічний інститут імені Ігоря Сікорського» (Україна).

Оцінювання рівня новизни продукції: інноваційний підхід

Стаття узагальнює аргументи та контраргументи в межах наукової дискусії з питання визначення структури та ступеня новизни товару відповідно до класифікації з точки зору фуннкціональної спрямованості новизни товару. Основною метою проведеного дослідження $\epsilon$ розробка власної методики оцінки ступеня новизни нового продукту як кількісної характеристики на основі порівняння з товаром-аналогом. Для побудови методології важливо попередне обгрунтування масштабу новизни продукту: регіонального, національного або глобального ринку. Від визначення необхідного масштабу новизни залежить вибір основного аналогового продукту та вибір групи споживачів. Систематизація літературних джерел та підходів до вирішення проблеми визначення рівня новизни товару засвідчила, що відсутня універсальна методика оцінки ступеня 
його новизни. Актуальність вирішення даної наукової проблеми полягає в оцінці міри новизни товару, оскільки насправді ринок перенасичений псевдо-новими товарами. Поняття новизни достатньо відносне і не має чітко визначених вимог. Дослідження питання кількісної оцінки новизни товару в статті здійснено в наступній логічній послідовності: визначається сутність та структура новизни, оцінюється рівень новизни по кожному виду і в результаті виводиться загальний інтегральний показник. Методичним інструментарієм проведеного дослідження стали математичні методи дій з матрицями та методи аналізу ієрархій попарних порівнянь, запропонованих Томасом Л. Сааті. Порівняння показників за різними критеріями проводиться за дев'ятибальною шкалою. Інтегральний показник рівня новизни нового продукту розраховується як середнє геометричне показників виробничої, ринкової та споживчої новизни. Визначення рівня новизни нового продукту здійснюється за шкалою від 0 до 1, що дозволяє визначити новизну як для кожного виду новизни так і для загального рівня новизни товару. Результати проведеного дослідження можуть бути корисними для оцінки підприємствами своїх нових товарів і як складова оцінки інноваційної діяльності підприємств.

Ключові слова: новизна, новий товар, види новизни, рівень новизни, структура новизни.

Manuscript received: 04.02.2019.

(C) The author(s) 2019. This article is published with open access at Sumy State University. 